\title{
Effects of cultivar and grazing initiation date on fall-grown oat for replacement dairy heifers ${ }^{1}$
}

\author{
W. K. Coblentz, ${ }^{\star 2}$ G. E. Brink, $†$ N. M. Esser, $\ddagger$ and J. S. Cavadinił \\ *USDA-Agricultural Research Service, US Dairy Forage Research Center, Marshfield, WI 54449 \\ †USDA- Agricultural Research Service, US Dairy Forage Research Center, Madison WI 53706 \\ ‡University of Wisconsin Marshfield Agricultural Research Station, Marshfield 54449
}

\section{ABSTRACT}

Fall-grown oat has shown promise for extending the grazing season in Wisconsin, but the optimum date for initiating grazing has not been evaluated. Our objectives for this project were (1) to assess the pasture productivity and nutritive value of 2 oat cultivars [Ogle and ForagePlus (OG and FP, respectively)] with lateSeptember (EG) or mid-October (LG) grazing initiation dates; and (2) to evaluate growth performance by heifers grazing these oat forages compared with heifers reared in confinement $(\mathrm{CON})$. A total of 160 gravid Holstein heifers ( 80 heifers/yr) were assigned to 10 research groups ( 8 heifers/group). Mean initial body weight was $509 \pm 40.5 \mathrm{~kg}$ in 2013 and $517 \pm 30.2 \mathrm{~kg}$ in 2014. Heifer groups were assigned to specific pastures arranged as a $2 \times 2$ factorial of oat cultivars and grazing initiation dates. Grazing heifer groups were allowed to strip-graze oat pastures for $6 \mathrm{~h}$ daily before returning to the barn, where they were offered a forage-based basal total mixed ration. Main effects of oat cultivar and sampling date interacted for forage characteristics in 2013, but not in 2014. During 2013, oat forage mass increased until early November before declining in response to freezing weather conditions, thereby exhibiting linear and quadratic effects of sampling date, regardless of oat cultivar. Similar trends over time were observed in 2014. For 2013, the maximum forage mass was 5,329 and $5,046 \mathrm{~kg} /$ ha for FP and OG, respectively, whereas the mean maximum forage mass for 2014 was $4,806 \mathrm{~kg} / \mathrm{ha}$. ForagePlus did not reach the boot stage of growth during either year of the trial; OG matured more rapidly, reaching the late-heading stage during

\footnotetext{
Received March 27, 2015.

Accepted May 17, 2015.

${ }^{1}$ Mention of trade names or commercial products in this article is solely for the purpose of providing specific information and does not imply either recommendation or endorsement by the USDA. The USDA is an equal opportunity provider and employer.

${ }^{2}$ Corresponding author: wayne.coblentz@ars.usda.gov
}

2013, but exhibited only minor maturity differences from FP in 2014. For 2013, average daily gain for CON did not differ from grazing heifer groups (overall mean $=0.63 \mathrm{~kg} / \mathrm{d}$ ); however, average daily gain from $\mathrm{FP}$ was greater than $\mathrm{OG}(0.68$ vs. $0.57 \mathrm{~kg} / \mathrm{d})$, and greater from EG compared with LG (0.82 vs. $0.43 \mathrm{~kg} / \mathrm{d})$. For 2013 , advantages in average daily gain for heifers grazing FP pastures were likely related to the greater energy density of FP oat throughout the fall that reached a maximum of $68.8 \%$ total digestible nutrients on November 27 compared with only $63.7 \%$ for OG on October 10 . During 2014, average daily gain from CON exceeded all grazing heifer groups (0.81 vs. $0.57 \mathrm{~kg} / \mathrm{d})$, and average daily gain from EG again exceeded LG (0.70 vs. 0.44 $\mathrm{kg} / \mathrm{d}$ ). These results suggest that delaying grazing until mid-October will consistently suppress heifer growth performance, particularly if rapidly maturing cultivars are used.

Key words: dairy heifer, energy, fall-grown oat, water-soluble carbohydrate

\section{INTRODUCTION}

Recently, studies have evaluated the potential of fall-grown oat (Avena sativa L.) to extend the grazing season throughout central Wisconsin (Coblentz et al., 2014), and extension recommendations have been developed to guide producers using this fall forage option (Coblentz et al., 2013a). The use of fall-grown oat specifically targets a grazing interval extending from late-September through late-November; during this time period, most perennial cool-season grasses become less productive, thereby posing management challenges for dairy producers seeking to meet intake requirements for lactating cows or heifers via grazed forages. Given this paradigm, forage options that support grazing dairy heifers or cows throughout October and early November are highly valued. Numerous characteristics of fall-grown oat forages are particularly well-suited to support fall grazing. The long-day photoperiod requirement for flowering (Dennis, 1984) is completely 
disrupted following August establishment, which results in a slower plant maturation rate compared with traditional spring-established oat forages (ContrerasGovea and Albrecht, 2006). Furthermore, our previous fall grazing study (Coblentz et al., 2014) demonstrated that oat forages established in early August often will mature only minimally after about October 15 , but will continue to accumulate forage mass for several weeks thereafter.

From a nutritional standpoint, several quality traits of fall-grown oat are unique and desirable within a grazing context. These include (1) reduced concentrations of fiber components and less extensive lignification; (2) improved fiber digestibility resulting directly from less lignification; (3) a strong tendency to accumulate water-soluble carbohydrates (WSC) as a result of winter hardening, particularly following freezing events; and (4) relatively stable energy density facilitated (in part) by accumulation of WSC in late October or November (Contreras-Govea and Albrecht, 2006; Coblentz and Walgenbach, 2010a; Coblentz et al., 2012a, 2013b, 2014). Despite these desirable traits, some management questions persist; among these, the identification of an appropriate grazing initiation date remains unresolved. Fall-oat forages typically exhibit very little regrowth potential, especially if the initial forage removal by grazing livestock occurs after plants have jointed and stem elongation has begun (Gunsaulis et al., 2008). Without potential for regrowth, initiating grazing too early will greatly restrict pasture productivity, whereas initiating grazing too late may depress the nutritive value of early-maturing cultivars, as well as risk forage loss due to the onset of winter weather, especially the necessary termination of grazing following heavy snowfall. Our objectives were to (1) assess the pasture productivity and forage characteristics of 2 fall-grown oat cultivars [Ogle (Schumitsch Seed, Inc., Antigo, WI) and ForagePlus (Kratz Farms, Slinger, WI); OG and FP, respectively] managed with 2 grazing initiation dates [late September or mid-October; early (EG) and late grazing (LG), respectively]; and (2) evaluate the growth performance of gravid heifers consuming these oat forages against the performance of heifers reared within a traditional confinement management system (CON).

\section{MATERIALS AND METHODS}

\section{Establishment of Pastures}

The experiment was conducted at the University of Wisconsin Marshfield Agricultural Research Station (Stratford, WI; $44^{\circ} 7^{\prime} \mathrm{N}, 90^{\circ} 1^{\prime} \mathrm{W}$ ), where pastures were established on a Withee silt loam (fine-loamy, mixed, frigid, Aeric Glossaqualfs) soil type. The 10-ha pasture research area was subdivided into 10 pastures; 8 of these pastures were 1.0 ha in size and served as the experimental units for all pasture measurements. The remaining 2 pastures were approximately 0.8-ha in size and were used as sacrifice pastures to train dairy replacement heifers to grazing, as well as to respect the electric-fencing system used throughout the grazing research unit. No data were collected or reported from these 2 training pastures. The pasture research site contained a centrally located drover's alley positioned with an east-west orientation, and rectangular pasture replicates of similar dimensions $(\sim 55.3 \times 181.0$ $\mathrm{m}$ ) were located on both the north and south sides of the drover's alley.

During early August 2013 and 2014, the entire pasture system was sampled for soil fertility (University of Wisconsin Soil and Forage Laboratory, Marshfield, WI). Respective soil tests for $\mathrm{pH}, \mathrm{P}, \mathrm{K}$, and $\mathrm{OM}$ were $6.9,41 \mathrm{mg} / \mathrm{kg}, 183 \mathrm{mg} / \mathrm{kg}$, and $36 \mathrm{~g} / \mathrm{kg}$ for 2013 , and $7.1,34 \mathrm{mg} / \mathrm{kg}, 163 \mathrm{mg} / \mathrm{kg}$, and $35 \mathrm{~g} / \mathrm{kg}$ for 2014 , respectively. Pastures were clean-tilled and then fertilized with urea (46-0-0) at a rate of $67 \mathrm{~kg}$ of N/ha on August 7, 2013, and August 11, 2014. Each year, 4 research pastures were assigned to OG oat, which was seeded at a rate of $108 \mathrm{~kg} / \mathrm{ha}$ in 2013 with a Case-International Harvester model 5300 grain drill (CNH Industrial, Racine, WI). Similarly, 4 pastures were seeded to FP oat by identical methods, which yielded a total of 8 pastures from which data were collected. Seeding procedures were similar in 2014, except that a John Deere model 1590 drill (Deere and Co., Moline, IL) was used to seed oat cultivars. Seeding dates for experimental oat pastures were August 8 and 9, 2013, and August 12,2014 . The 2 cultivars chosen for our study exhibit distinctly different maturity characteristics: OG oat is considered a mid-maturity, grain-type oat cultivar, whereas FP has been selected specifically for foragerelated traits and consistently exhibits a slower rate of maturation (Mochon and Conley, 2014) when planted in the spring. These maturation differences are known to be exacerbated with fall establishment (Coblentz et al., 2011).

\section{Management of Heifer Groups}

Treatments. All procedures for handling and care of dairy heifers within this trial were approved by the Research Animal Resources Committee of the University of Wisconsin-Madison (Protocol \#A01479). Gravid Holstein heifers (80 heifers/yr) weighing $509 \pm 40.5 \mathrm{~kg}$ in 2013 and $517 \pm 30.2 \mathrm{~kg}$ in 2014 were stratified by 
weight and assigned to 1 of 10 identical research pens ( 8 heifers/pen) located within a pole-type barn with natural cross ventilation. All heifers were confirmed pregnant by the attending veterinarian before initiating the trial to avoid breeding heifers by AI during the grazing trial. Each research pen was equipped with continuous access to fresh water, 8 freestalls with multicelled, rubber-packed mattresses, a mechanical alleyscraping system, and bunk space adjacent to a drive-by feed alley that allowed all heifers within each research pen to eat simultaneously. During both 2013 and 2014, the 10 research pens were assigned to 1 of 5 treatments: (1) FP with an EG grazing initiation date; (2) FP with a LG grazing initiation date; (3) OG with an EG grazing initiation date; (4) OG with a LG grazing initiation date; or (5) CON (no grazing). Therefore, treatments were arranged as a $2 \times 2$ factorial of oat cultivars (FP or $\mathrm{OG}$ ) and grazing initiation dates (EG or LG) plus a CON. Within each year of the trial, there were 2 replications of all treatment combinations.

Approved standards of animal care for this trial (Protocol \#A01479) were somewhat unique, primarily because they did not authorize heifers to remain on experimental pastures overnight because of potential for cold temperatures and precipitation in the form of snow or ice, particularly during November. Therefore, heifers grazed research pastures for $6 \mathrm{~h}$ daily, from approximately 0830 to $1430 \mathrm{~h}$, and then were returned to their assigned pen within the research barn until the following morning. Periodically, weather conditions prohibited heifers from grazing; this occurred on 16 of 67 and 12 of 57 possible grazing days during 2013 and 2014, respectively. Decisions to forgo grazing were associated primarily with heavy rains or wet conditions that would result in significant pugging of the soil surface by heifers. Based on visual observation and previous experience, these events resulted in a rough soil surface after the ground froze on which heifers would refuse to walk. Whenever conditions were unsuitable for grazing, all pens of grazing heifers were retained within the research barn and managed in an identical manner to CON groups.

Basal Diet and Orts. A basal diet composed of oatlage and alfalfa haylage (Table 1) was dispensed to the control groups at 0900 and $1530 \mathrm{~h}$ in proportions accounting for 60 and $40 \%$ of the total daily allotment, respectively. At $1530 \mathrm{~h}$, the basal TMR also was offered to each pen of heifers returning from pasture for ad libitum intake. After delivery of the diet at $1530 \mathrm{~h}$, the TMR was top-dressed with ground corn during both years of the trial at a mean rate of $0.40 \mathrm{~kg} /$ heifer per day, which also served as a carrier for a low-phosphorus mineral package (Table 1) offered at a rate of $158 \mathrm{~g} /$ heifer per day. Regardless of treatment, the basal diet was offered for ad libitum intake by managing daily offerings to a defined bunk score of 2 , where $0=$ no feed particles remaining, $1=$ only scattered feed particles remaining, $2=$ numerous particles remaining but the concrete floor still easily visible, or $3=$ feed particles completely covering the concrete bunk floor (Hoffman et al., 2008). Bunks were scored each morning, and the amount of TMR was adjusted daily on this basis to maintain the pre-established target bunk score of 2 . Normally, a bunk score of 0 triggered a $6 \%$ increase in the daily diet allocation, calculated on an as-is basis, whereas bunk scores of 1 or 3 triggered an increase or decrease of $3 \%$, respectively. Samples of the basal diet were obtained daily, frozen $\left(-20^{\circ} \mathrm{C}\right)$, and then composited by week for analysis. The weekly composite of the basal diet was analyzed by the University of Wisconsin Soil and Forage Laboratory for CP by a macro-Kjeldahl procedure (AOAC International, 1998; method 988.05); ash by combustion in a muffle furnace at $500^{\circ} \mathrm{C}$ for $6 \mathrm{~h}$; starch (model 2700D, Yellow Springs Instrument Co., Yellow Springs, OH); ether extract (AOAC, 1990; method 920.29); Ca, K, and $\mathrm{Mg}$ by atomic absorption spectroscopy; and $\mathrm{P}$ by colorimetric methodology (Schulte et al., 1987). In addition, concentrations of NDF were quantified as described by Goering and Van Soest (1970) with both heat-stable amylase and sodium sulfite included within the NDF solution. A 48-h in vitro digestion of NDF was conducted in buffered rumen fluid using procedures described in detail by Kruse et al. (2010) and Coblentz et al. (2012b). In addition, independent $\mathrm{NDF}$ and $\mathrm{ADF}$ residues were generated following boiling for $1 \mathrm{~h}$ in neutral- or acid-detergent solutions, respectively; residues were then analyzed for residual CP (NDICP and ADICP, respectively) by the macro-Kjeldahl procedure described previously. For determinations of NDICP, the NDF solution contained heat-stable amylase, but sodium sulfite was omitted to prevent excessive removal of $\mathrm{CP}$ associated with the forage fiber matrix; for $\mathrm{ADF}$, the isolation of $\mathrm{ADF}$ residues before quantifying residual $\mathrm{CP}$ was conducted nonsequentially (Van Soest et al., 1991). Energy calculations for the TMR were made as described by NRC (2001).

Orts also were sampled daily and composited by week; each morning, refusals were swept from each feed bunk, placed in a large (tared) plastic tub, mixed thoroughly, weighed, and then subsampled ( $200 \mathrm{~g})$. During each week of the trial, daily subsamples of orts from each pen were placed in sealed freezer bags, frozen $\left(-20^{\circ} \mathrm{C}\right)$, and then composited by pen. A subsample $(\sim 400 \mathrm{~g})$ of weekly refusals from each pen was placed in a paper bag and then dried to constant weight under forced air at $55^{\circ} \mathrm{C}$ to determine the concentration of DM within the orts. 
Table 1. Mean composition of the forage TMR offered to dairy heifers during 2013 and $2014^{1,2}$

\begin{tabular}{|c|c|}
\hline Item & $\begin{array}{l}\text { Mean } \\
\text { composition }\end{array}$ \\
\hline \multicolumn{2}{|l|}{ Ingredient, $\%$ of DM } \\
\hline Alfalfa haylage & 39.1 \\
\hline Oatlage & 60.9 \\
\hline \multicolumn{2}{|c|}{$\begin{array}{l}\text { Nutrient composition, } \% \text { of DM (unless otherwise } \\
\text { indicated) }\end{array}$} \\
\hline DM, $\%$ of wet weight & 32.1 \\
\hline $\mathrm{CP}$ & 12.4 \\
\hline NDF & 58.3 \\
\hline NDF digestibility, $\%$ of NDF & 57.9 \\
\hline $\mathrm{ADF}$ & 38.8 \\
\hline $\mathrm{NDICP}^{3}$ & 2.77 \\
\hline $\mathrm{ADICP}^{3}$ & 1.14 \\
\hline Starch & 3.02 \\
\hline Ether extract & 2.26 \\
\hline Ash & 9.26 \\
\hline $\mathrm{P}$ & 0.32 \\
\hline $\mathrm{Ca}$ & 0.63 \\
\hline $\mathrm{K}$ & 2.47 \\
\hline $\mathrm{Mg}$ & 0.17 \\
\hline \multicolumn{2}{|l|}{ Energy estimates } \\
\hline TDN, $\%$ & 60.0 \\
\hline ME, Mcal/kg & 2.22 \\
\hline $\mathrm{NE}_{\mathrm{G}}, \mathrm{Mcal} / \mathrm{kg}$ & 0.78 \\
\hline $\mathrm{NE}_{\mathrm{M}}, \mathrm{Mcal} / \mathrm{kg}$ & 1.37 \\
\hline
\end{tabular}

${ }^{1}$ Analyses of TMR conducted by the University of Wisconsin Soil and Forage Analysis Laboratory, Marshfield, Wisconsin.

${ }^{2}$ All heifers, regardless of treatment, received a mean allotment of 0.40 $\mathrm{kg}$ /heifer per day of top-dressed ground corn during 2013 and 2014 similarly, each heifer received $158 \mathrm{~g} / \mathrm{d}$ of a commercial mineral mix daily during both years of the trial. Mineral package contained $72.1 \%$ calcium carbonate, $16.5 \%$ salt, $3.35 \%$ sulfur, $2.95 \%$ selenium 1600 , $1.50 \%$ vitamin A, $0.75 \%$ mineral oil, $0.71 \%$ copper sulfate, $0.69 \%$ vitamin $\mathrm{E}(50 \%), 0.64 \%$ zinc sulfate, $0.51 \%$ vitamin $\mathrm{D}, 0.09 \%$ iodine mix $0.005 \%$ magnesium sulfate, $0.005 \%$ cobalt carbonate, $0.005 \%$ manganese oxide $(60 \%)$, and $0.26 \%$ thiamine.

${ }^{3} \mathrm{NDICP}=$ neutral detergent-insoluble $\mathrm{CP} ; \mathrm{ADICP}=$ acid detergentinsoluble $\mathrm{CP}$

Training and Adaption. Approximately 2 wk before data collection was initiated each year, heifers were trained to the electric wire and then adapted further to grazing stockpiled oat forage as described previously (Coblentz et al., 2013a, 2014). Because heifers had no previous grazing experience, they were trained initially to an electrified wire placed inside a fenced corral with a concrete floor. Groups of about 16 heifers were allowed access to the corral and the electric training wire for approximately $0.5 \mathrm{~h}$ before they were rotated out of the corral, then additional groups of 16 animals were permitted access. Heifers were evaluated during at least 2 of these training sessions before they were allowed access to sacrifice pastures, and any animal that did not adapt well was eliminated from consideration for the trial. During the week immediately preceding the initiation of data collection, heifers were further comingled into 2 larger groups of about 32 animals each, and slowly escorted to the sacrifice pastures through the centrally located drover's alley, where they were allowed to adjust to the pasture, electric wire, and initiate grazing for about $1 \mathrm{~h}$; however, access time on the sacrifice pastures was increased subsequently to 4 to $5 \mathrm{~h}$ daily during the week of pasture adaptation. At the end of the training and adaptation period, heifers were sorted into permanent groups of 8 heifers each, and then all groups (including $\mathrm{CON}$ ) were assigned to a specific residence pen within the barn, as well as a specific research pasture (grazing groups only). Grazing was initiated on September 30, 2013, and September 30, 2014 for EG, and on October 14, 2013, and October 9, 2014, for groups assigned to LG. The trial was terminated on December 5, 2013 and November 25, 2014.

Heifer Measurements. On d 1 through 3 of data collection, weights were obtained for all heifers at 0730 $\mathrm{h}$ before feeding $(\mathrm{CON})$ or grazing using a cattle chute (Real Tuff, Clearbrook, MN) fitted with an electronic scale (Tru-Test Inc., Mineral Wells, TX). Body weights obtained the first $3 \mathrm{~d}$ of the trial were averaged to determine an initial BW for each heifer. During this time period, 2 trained evaluators also assessed BCS for all heifers on a scale of 1 to 5 , where $1=$ emaciated and $5=$ obese (Wildman et al., 1982), and increments of 0.5 units were used to best describe the body condition of each heifer. A final mean BW was obtained by weighing heifers at $0730 \mathrm{~h}$ for 3 consecutive days at the conclusion of the trial, and a final BCS was obtained as described previously during this final 3 -d period of weight determination.

\section{Daily Pasture Management and Forage Allocation}

As described previously, utilization of fall-grown oat is a form of stockpiling forage for deferred grazing. Fallgrown oat will winterkill in Wisconsin, and previous research has shown that these forages offer very poor regrowth potential (Gunsaulis et al., 2008), especially after jointing has occurred. As a result of these factors, there was no need to manage grazing aftermath with respect to stubble height, rest intervals, or effects of heifer traffic. Only a single-strand lead wire was used to control grazing, primarily to prevent heifers from wasting forage by walking, lying, urinating, or defecating on ungrazed portions of the pasture. At the start of data collection, the lead wire was positioned approximately $10 \mathrm{~m}$ into each pasture to prevent excessive crowding while heifers adjusted further to their daily grazing routine, as well as their permanently assigned pastures. After 3 to $4 \mathrm{~d}$, the lead wire was advanced daily by a trained technician to provide $7.9 \mathrm{~kg}$ of DM/heifer per day of oat forage, which was estimated to be about $80 \%$ 
of their expected DMI. This daily allotment required advancement of the lead wire by 1.9 to $5.5 \mathrm{~m}$ daily during 2013 , and by 1.9 to $6.9 \mathrm{~m}$ during 2014 . The exact width of pastures varied slightly, and advancements of the lead wire were recalculated weekly for each pasture based on forage mass, DM concentration of the forage, and pasture width. Regardless of pasture, the lead wire in each pasture was a single strand of poly-tape supported by 4 or 5 tread-in fencing posts. Accuracy and precision of lead-wire advancements were ensured by using a lightweight polyvinyl chloride pipe (outside diameter $=2.5 \mathrm{~cm})$ that was marked in $0.3-\mathrm{m}(1-\mathrm{ft})$ increments with black electrical tape to guide placement of the tread-in posts. The daily allotment of fall oat represented a slight decrease from our previous trial (8.5 to $9.0 \mathrm{~kg}$ of $\mathrm{DM} /$ heifer per day; Coblentz et al., 2014) that included similar forages, grazing techniques, and heifers of comparable weight. The reduced daily forage allotment used in this study was based on an in-depth evaluation of both pre- and postgrazed (residual) forages during the previous trial (Coblentz et al., 2014), which suggested utilization could be improved, especially if plant maturity exceeded the boot stage of growth.

\section{Pasture Sampling Procedures}

Each research pasture was sampled weekly throughout the trial by clipping two $0.25-\mathrm{m}^{2}$ frames on the ungrazed side of the lead wire with hand shears to a 2.5 -cm stubble height. Each frame was placed in close proximity to the lead wire, but placement was limited to the area that would be grazed within that specific week. Forage clippings were dried in paper bags to constant weight under forced air at $55^{\circ} \mathrm{C}$, and forage dry weight was then extrapolated to estimate forage mass on a kilogram of DM per hectare basis. Following drying, forage obtained from each pasture was divided into 2 subsamples; subsequently, one portion was ground through a Thomas Model 4 Wiley Mill (Thomas Scientific, Swedesboro, NJ) equipped with a 1-mm screen and retained for analysis of whole-plant nutritive value, whereas the remaining portion was retained for separation into leaf and stem tissues. Concurrent with the weekly sampling of forages, canopy height was measured on an as-is basis. An exception was made whenever plants lodged following snowfall events. In those cases, oat plants were held erect before measurements were taken. In addition, 3 tillers were selected at random and assessed for growth stage using a linear descriptive model (Stauss, 1994). Stages of growth were identified as tillering $=20$ to 29 ; stem elongation $=30$ to 39 ; booting $=40$ to 49 ; emergence of inflorescence
$=50$ to 59. Oat is considered to be a long-day plant (Dennis, 1984), and it is unlikely that viable seed can be produced following the fall establishment procedures described for our trial; therefore, no attempt was made to stage plants beyond full emergence of seedhead and peduncle (growth stage $=59$ ). Percentages of leaf were determined by hand-separating leaf tissue from the leaf sheath, stem, and any reproductive structures (awns, inflorescence, or seed). The leaf sheath and all of the reproductive structures were considered stem components. Any weeds were discarded before conducting leaf and stem separations.

\section{Laboratory Analyses of Oat-Pasture Forages}

All dried, ground, whole-plant oat forages were analyzed sequentially for NDF, ADF, and ADL using batch procedures outlined by Ankom Technology Corp. (Macedon, NY) for an ANKOM200 Fiber Analyzer. The NDF solution included heat-stable $\alpha$-amylase, but not sodium sulfite. Whole-plant ash was determined from a 1.0-g subsample of each forage following combustion in a muffle furnace at $500^{\circ} \mathrm{C}$ for $6 \mathrm{~h}$. Concentrations of $\mathrm{CP}$ were assessed by a rapid combustion procedure (AOAC, 1998, method 990.03; Elementar Americas Inc., Mt. Laurel, NJ) and calculated as the percentage of $\mathrm{N} \times 6.25$. Water-soluble carbohydrates were quantified using the phenol-sulfuric acid reaction with final concentrations determined colorimetrically (Dubois et al., 1956). The energy density of each forage was calculated based on the summative equation (Weiss et al., 1992; NRC, 2001) using the ADL option for estimating truly digestible fiber. Inputs of NDICP and ADICP are required to calculate TDN by the summative equation (NRC, 2001), and these were obtained from each sample following nonsequential extraction in neutral and acid detergent, respectively, using the aforementioned batch procedures of Ankom Technology Corp. For this purpose, the NDF solution contained no sodium sulfite, which is known to cleave disulfide bonds and dissolve cross-linked proteins, thereby reducing recovery of $\mathrm{CP}$ from NDF residues (Van Soest et al., 1991). Residual $\mathrm{CP}$ following these extractions was quantified by the combustion procedure described previously (AOAC International, 1998). Concentrations of NDICP and ADICP were used only to calculate TDN and are not otherwise reported or discussed.

\section{Statistics}

All forage measurements were analyzed by PROC MIXED of SAS Institute (2010) as a split-plot design with oat cultivar and week as the whole-plot and sub- 
plot treatment terms, respectively. Oat cultivars were assigned randomly to research pastures; therefore, pasture replication nested within cultivar was declared random, and was used to test the whole-plot term (cultivar) for significance. The EG and LG designations for grazing initiation had no relevance with respect to ungrazed forage characteristics and were not included in the statistical model. Responses were evaluated for linear, quadratic, cubic, or quartic trends over time with orthogonal contrasts. Orthogonal coefficients were based on 9 and 8 sampling weeks during 2013 and 2014, respectively; on the basis of these differences in trial length across years, each year was evaluated independently.

Normal climatic conditions within central Wisconsin will limit the time interval for this grazing application to approximately $60 \mathrm{~d}$. Although providing forage for grazing livestock during October and November is important to dairy producers seeking maximum extension of the grazing season, the utility of heifer performance data based on a short 2-mo evaluation period is potentially problematic, particularly when coupled with periodic, but necessary, decisions to forgo grazing due to inclement weather. It also should be noted that the conditions imposed on our study to meet approved standards of animal care and to navigate difficult climatic conditions during late fall are not inconsistent with common production management. Many heifers throughout the region, particularly those on small and mid-sized dairies, have access to some type of shelter and are offered harvested forages during this time period, but also may have access to perennial or (potentially) annual pasture. Although heifer performance data have been analyzed, reported, and discussed, some caution is advised with respect to interpretation because of the atypical limitations described for the trial.

For heifer performance data, the pen or heifer group was considered to be the experimental unit. Initially, heifer performance data were analyzed as a split-plot design with year as the whole-plot treatment term and management system (FP-EG, FP-LG, OG-EG, OG-LG, or $\mathrm{CON}$ ) as the subplot term. However, interactions of year and management system were observed for most response variables; therefore, data were reanalyzed by year with PROC MIXED of SAS Institute (2010) as a completely randomized design with 2 replications of each management treatment. Least-square treatment means were tested for significance with 4 orthogonal contrasts: (1) CON versus all grazing heifer groups; (2) FP versus OG; (3) EG versus LG; and (4) the interaction of oat cultivar and grazing initiation date. Significance was declared at the $P=0.05$ level of confidence, unless otherwise stated.

\section{RESULTS}

\section{Weather Data}

Expected 30-yr norms (NOAA, 2002), as well as monthly means for temperature and precipitation for June through December of 2013 and 2014, are shown in Figures 1 and 2, respectively. Generally, precipitation was well below normal from July through September of 2013; in particular, the deficit in August was $83 \mathrm{~mm}$ and the total deficit for this 3-mo period was $144 \mathrm{~mm}$. In contrast, precipitation during October 2013 (182 $\mathrm{mm}$ ) exceeded the 30-yr norm by $118 \mathrm{~mm}$. The other unique aspect of 2013 was the colder than normal temperatures during November and December; respective mean monthly temperatures were -1.1 and $-11.4^{\circ} \mathrm{C}$, which restricted potential for late-fall forage growth. For 2014, the precipitation pattern differed sharply from 2013, with $176 \mathrm{~mm}$ of precipitation occurring during August, but precipitation during other months was more consistent with expected norms than observed in 2013. An additional stark difference between 2013 and 2014 occurred with respect to snowfall during November, which totaled $10.2 \mathrm{~cm}$ in 2013 but was more than 4 times greater in $2014(45.2 \mathrm{~cm})$.

\section{Pasture Evaluations}

Agronomic Characteristics 2013. During 2013, the interaction of oat cultivar and sampling date was significant $(P<0.05)$ for most response variables, therefore data are presented (Table 2) as interaction means. For 2013, the more aggressive maturation characteristics of OG were clearly evident; OG reached the early-heading stage of growth $($ stage $=50)$ by the initial sampling date on September 30 and matured further to full extension of the peduncle by November 13. In contrast, FP did not reach boot stage on any sampling date during 2013. Generally, maturation responses were explained by strong linear $(P<0.001)$ effects of sampling date for both cultivars, although additional cubic $(P=0.014)$ and quartic $(P=0.002)$ effects were observed for FP and OG, respectively. The DM concentrations within oat cultivars increased slowly through November 6 before exhibiting sharp increases in response to freezing events; for OG, concentrations of DM nearly doubled (18.9 vs. $35.2 \%$ ) between November 6 and 13, and a similar response was observed for FP. For both cultivars, these responses were explained by multiple polynomial effects $(P \leq 0.005)$. Canopy height also reflected the accelerated maturation rate for OG compared with FP; the canopy height for OG was numerically greater on all sampling dates than 


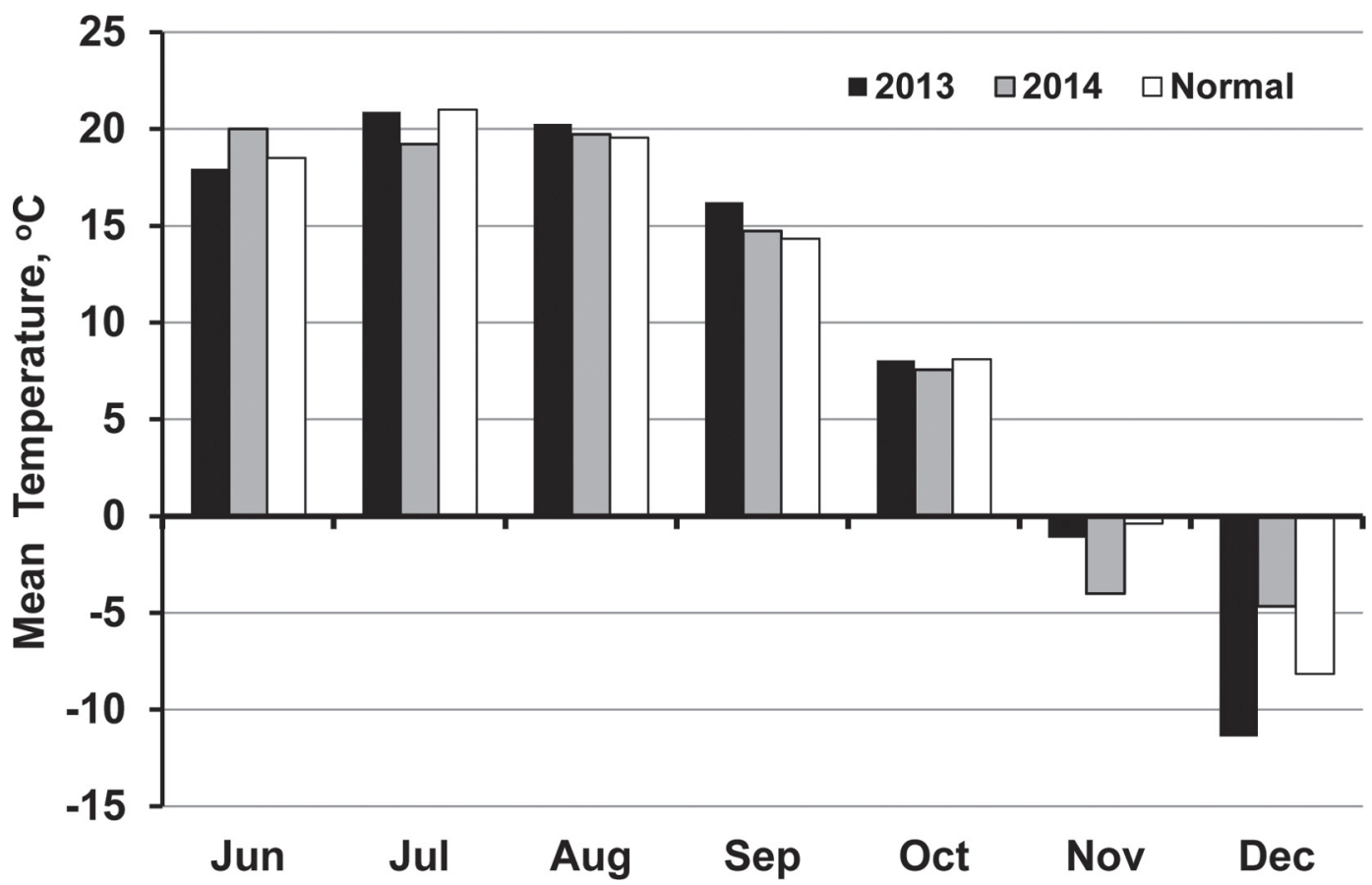

Figure 1. Mean monthly temperature during June through December of 2013 and 2014, as well as the 30-yr norm during that time period (NOAA, 2002), at Marshfield, Wisconsin.

observed for FP, and the mean difference between cultivars across all sampling dates was $14 \mathrm{~cm}$ (71 vs. 57 $\mathrm{cm} ; P=0.002)$. Within cultivar, the canopy height for
FP increased to maxima of $67 \mathrm{~cm}$ on both October 17 and 22 before declining in response to freezing events in November, thereby exhibiting linear, quadratic, and

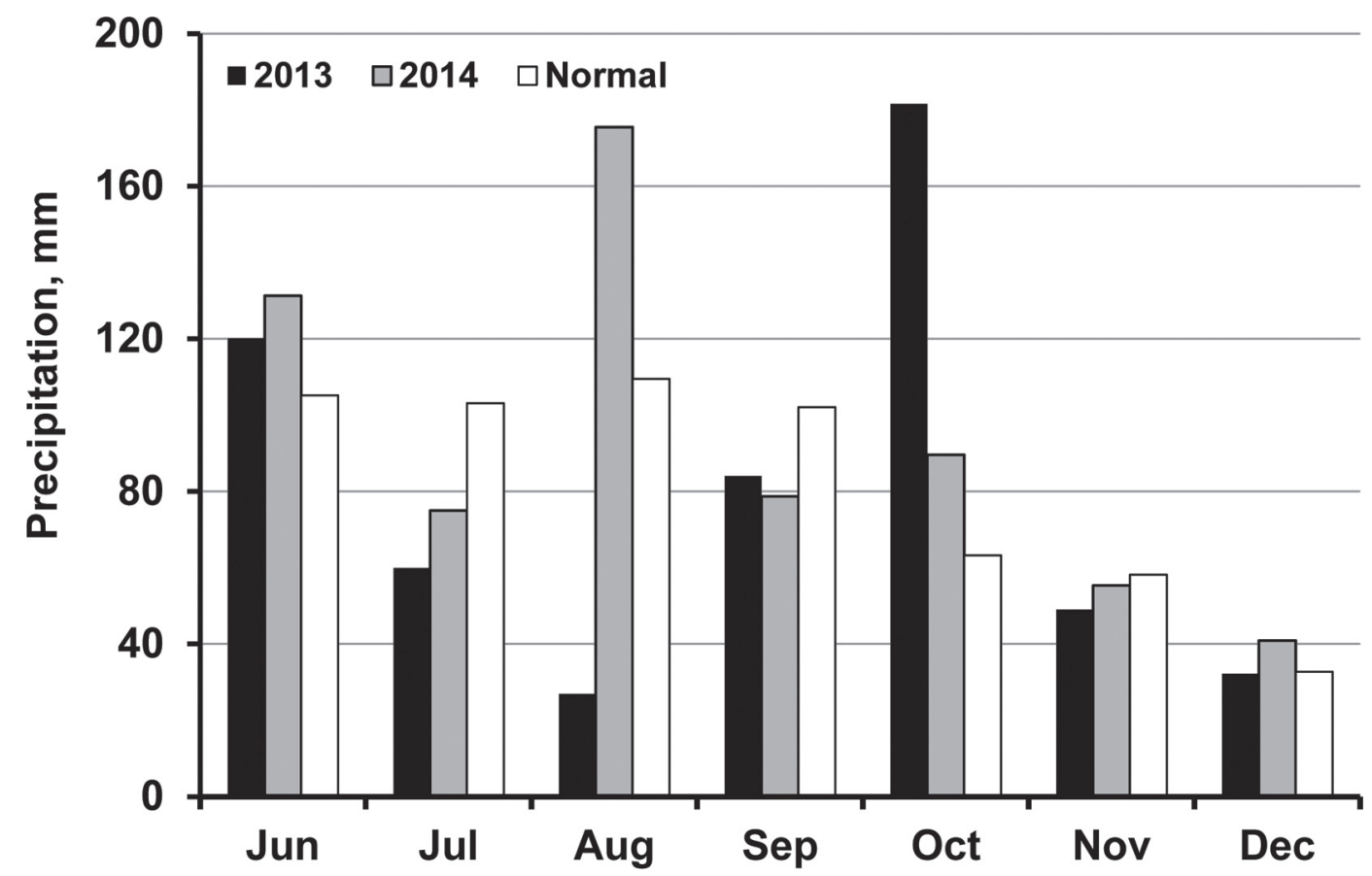

Figure 2. Monthly precipitation during June through December of 2013 and 2014, as well as the 30-yr norm for precipitation during that time period (NOAA, 2002), at Marshfield, Wisconsin. 
Table 2. Agronomic characteristics for ForagePlus (FP; Kratz Farms, Slinger, WI) and Ogle (Schumitsch Seed Inc., Antigo, WI) oat pastures grazed during September through November 2013 at Marshfield, Wisconsin

\begin{tabular}{|c|c|c|c|c|c|c|c|c|c|c|}
\hline \multirow[b]{2}{*}{ Item } & \multicolumn{2}{|c|}{$\begin{array}{c}\text { Growth } \\
\text { stage, }{ }^{1} \text { no. }\end{array}$} & \multicolumn{2}{|c|}{$\begin{array}{l}\text { Forage } \\
\text { DM, \% }\end{array}$} & \multicolumn{2}{|c|}{$\begin{array}{l}\text { Canopy } \\
\text { height, cm }\end{array}$} & \multicolumn{2}{|c|}{$\begin{array}{l}\text { Forage mass, } \\
\mathrm{kg} \text { of } \mathrm{DM} / \mathrm{ha}\end{array}$} & \multicolumn{2}{|c|}{$\begin{array}{c}\text { Leaf percentage, } \\
\% \text { of DM }\end{array}$} \\
\hline & $\mathrm{FP}$ & Ogle & $\mathrm{FP}$ & Ogle & $\mathrm{FP}$ & Ogle & $\mathrm{FP}$ & Ogle & $\mathrm{FP}$ & Ogle \\
\hline \multicolumn{11}{|l|}{ Date } \\
\hline September 30 & 32 & 50 & 10.7 & 13.1 & 52 & 61 & 2,423 & 2,681 & 72.6 & 42.0 \\
\hline October 10 & 32 & 54 & 11.3 & 14.0 & 64 & 79 & 2,508 & 3,084 & 69.8 & 39.1 \\
\hline October 17 & 33 & 55 & 10.8 & 13.9 & 67 & 75 & 4,729 & 4,264 & 61.2 & 35.1 \\
\hline November 6 & 35 & 56 & 13.7 & 18.9 & 62 & 73 & 4,311 & 4,177 & 57.5 & 32.7 \\
\hline November 13 & 37 & 59 & 22.0 & 35.2 & 47 & 74 & 5,329 & 5,046 & 55.7 & 31.4 \\
\hline November 20 & 36 & 56 & 21.4 & 34.1 & 45 & 65 & 4,467 & 4,128 & 50.5 & 27.8 \\
\hline November 27 & 35 & 58 & 24.8 & 34.5 & 46 & 64 & 3,610 & 3,632 & 54.7 & 30.0 \\
\hline SEM & \multicolumn{2}{|c|}{0.7} & \multicolumn{2}{|c|}{0.72} & \multicolumn{2}{|c|}{2.9} & \multirow{2}{*}{\multicolumn{2}{|c|}{237.5}} & \multicolumn{2}{|c|}{2.02} \\
\hline Contrast, ${ }^{2} P>F$ & & & & & & & & & & \\
\hline Linear & $<0.001$ & $<0.001$ & $<0.001$ & $<0.001$ & $<0.001$ & 0.066 & $<0.001$ & $<0.001$ & $<0.001$ & $<0.001$ \\
\hline
\end{tabular}

${ }^{1}$ Stage of growth identified as 20-29, tillering; 30-39, stem elongation; 40-49, booting; and 50-59, emergence of inflorescence (Stauss, 1994). Because oat is a long-day plant, and it is unclear whether viable seed can be produced with fall establishment, no attempt was made to stage plants beyond full emergence of seedhead and peduncle (growth stage $=59$ ).

${ }^{2}$ Linear, quadratic, cubic, and quartic effects of sampling date on each response variable.

cubic effects $(P<0.001)$. In contrast, the maximum canopy height for OG was observed on October 10, followed by a steady decline thereafter that was less affected by freezing events than FP. These responses were explained by multiple higher-ordered effects $(P \leq$ $0.021)$, but only tended to exhibit linear $(P=0.066)$ character. Differences in maturation rate and canopy height had no effect on available forage mass; evaluated across all dates, OG and FP did not differ $(3,549$ vs. $3,498 \mathrm{~kg} / \mathrm{ha} ; P=0.781$ ). Moreover, both cultivars exhibited linear and quadratic effects $(P<0.001)$, in which forage mass was maximized $(\geq 5,046 \mathrm{~kg} / \mathrm{ha})$ on November 13 before declining sharply to about 3,600 $\mathrm{kg} /$ ha by November 27. Percentages of leaf for both cultivars declined in primarily a linear $(P<0.001)$ pattern over time; however, quadratic character was also detected $(P \leq 0.026)$. Most importantly, the percentage of leaf tissue was numerically greater for FP than for OG on every sampling date, and considered collectively across all dates was nearly double that of OG (60.1 vs. $33.6 \% ; P<0.001)$.

Agronomic Characteristics 2014. Unlike 2013, differences in maturation rate between oat cultivars during 2014 were much less distinct, and the interaction of oat cultivar and sampling date generally was not significant $(P>0.05)$; therefore, only main effect means are reported (Table 3) and discussed. The mean growth stage across oat cultivars remained within the stem-elongation stages of growth on all sampling dates, but increased over time with linear $(P<0.001)$ and quadratic $(P<0.001)$ effects. Considered across all dates, OG demonstrated more rapid maturation characteristics, but from a practical perspective, these were minimal (stage 35 vs. stage $32 ; P<0.001$ ) compared with 2013. Concentrations of DM increased to a maximum of $17.3 \%$ in primarily a linear $(P \leq$ $0.001)$ pattern across sampling dates; however, this response was somewhat erratic on the final sampling dates because of snowfall events that required sampling procedures to be performed on partially snow-covered forages, thereby resulting in additional higher-ordered effects $(P \leq 0.001)$. As observed for 2013, the canopy height for OG was greater than observed for FP on all sampling dates, resulting in a main effect difference between cultivars ( 62 vs. $53 \mathrm{~cm} ; P=0.002$ ). Although multiple polynomial trends were detected $(P \leq 0.006)$, canopy height generally changed in a quadratic $(P<$ 0.001) fashion over time, increasing from 54 to $66 \mathrm{~cm}$ by October 27 before declining to a minimum of $50 \mathrm{~cm}$ in response to freezing and snowfall events by the final sampling date. From a practical perspective, available forage mass also changed in a quadratic $(P<0.001)$ pattern across sampling dates, reaching a maximum of $4,806 \mathrm{~kg} / \mathrm{ha}$ on November 6 before declining thereafter. Considered across all sampling dates, greater forage mass was observed for OG than for FP (4,034 vs. 3,489 $\mathrm{kg} / \mathrm{ha} ; P=0.035)$. The percentage of leaf in oat forages during 2014 remained $\geq 54.5 \%$ on all sampling dates, with a maximum of $70.3 \%$ on September 30. Overall, percentages of leaf changed in primarily a quadratic 
Table 3. Agronomic characteristics for ForagePlus (FP; Kratz Farms, Slinger, WI) and Ogle (Schumitsch Seed Inc., Antigo, WI) oat pastures grazed during September through November 2014 at Marshfield, Wisconsin

\begin{tabular}{|c|c|c|c|c|c|}
\hline Treatment & $\begin{array}{c}\text { Growth } \\
\text { stage, }{ }^{1} \text { no. }\end{array}$ & $\begin{array}{l}\text { Forage } \\
\text { DM, \% }\end{array}$ & $\begin{array}{l}\text { Canopy } \\
\text { height, } \mathrm{cm}\end{array}$ & $\begin{array}{c}\text { Forage } \\
\text { mass, kg of DM/ } \\
\text { ha }\end{array}$ & $\begin{array}{l}\text { Leaf } \\
\text { percentage, } \\
\% \text { of DM }\end{array}$ \\
\hline \multicolumn{6}{|l|}{ Date } \\
\hline September 30 & 31 & 11.5 & 54 & 2,435 & 70.3 \\
\hline October 6 & 32 & 13.0 & 55 & 2,666 & 66.3 \\
\hline October 15 & 33 & 13.1 & 61 & 3,874 & 60.7 \\
\hline October 21 & 33 & 14.5 & 64 & 4,508 & 58.6 \\
\hline October 27 & 32 & 14.6 & 66 & 4,535 & 54.8 \\
\hline November 6 & 35 & 17.3 & 59 & 4,806 & 54.5 \\
\hline November 12 & 36 & 12.0 & 52 & 3,888 & 61.9 \\
\hline November 17 & 38 & 16.1 & 50 & 3,378 & 66.3 \\
\hline SEM & 0.5 & 0.42 & 1.6 & 172.4 & 1.03 \\
\hline \multicolumn{6}{|l|}{ Cultivar } \\
\hline ForagePlus & 32 & 13.7 & 53 & 3,489 & 66.8 \\
\hline Ogle & 35 & 14.3 & 62 & 4,034 & 56.6 \\
\hline SEM & 0.3 & 2.4 & 1.3 & 142.3 & 0.60 \\
\hline \multicolumn{6}{|l|}{ Contrast $^{2}$} \\
\hline Linear & $<0.001$ & $<0.001$ & 0.006 & $<0.001$ & $<0.001$ \\
\hline Quadratic & $<0.001$ & 0.001 & $<0.001$ & $<0.001$ & $<0.001$ \\
\hline Cubic & 0.079 & 0.278 & 0.653 & 0.016 & 0.005 \\
\hline Quartic & 0.413 & $<0.001$ & $<0.001$ & 0.006 & 0.167 \\
\hline Cultivar & $<0.001$ & 0.109 & 0.002 & 0.035 & $<0.001$ \\
\hline
\end{tabular}

${ }^{1}$ Stage of growth identified as 20-29, tillering: 30-39, stem elongation; 40-49, booting; and 50-59, emergence of inflorescence (Stauss, 1994). Because oat is a long-day plant, and it is unclear whether viable seed can be produced with fall establishment, no attempt was made to stage plants beyond full emergence of seedhead and peduncle (growth stage $=59$ ).

${ }^{2}$ Contrasts: linear, quadratic, cubic, and quartic effects of sampling date, and effect of oat cultivar.

$(P<0.001)$ pattern, with the minimum occurring on November 6; across all dates, percentages of leaf for FP were greater than observed for OG (66.8 vs. $56.6 \%$; $P$ $<0.001)$.

Forage Nutritive Value 2013. As observed for agronomic characteristics during 2013, main effects of oat cultivar and sampling date generally interacted for measures of nutritive value; therefore, only interaction means are presented (Table 4). Concentrations of NDF for FP oat varied minimally across sampling dates (Table 4), differing only by 2.1 percentage units ( 46.6 vs. $48.7 \%$ ) at the beginning and end of the trial. In practical terms, this response largely could be considered static, but a cubic response trend was detected $(P=0.034)$. Similarly, concentrations of ADF within FP forages also exhibited a cubic effect $(P=0.006)$ of sampling dates; however, the overall range was narrow (23.4 to $28.8 \%$ ), and concentrations on the initial and final sampling dates were nearly identical (24.9 and $24.7 \%$, respectively). Acid-detergent lignin concentrations were very low across all dates, and exhibited no polynomial trends related to sampling date (overall mean $=0.98 \% ; P \geq 0.683)$. In contrast, fiber components (NDF, ADF, and ADL) for OG increased in primarily linear $(P<0.001)$ patterns across sampling dates; additional higher-ordered effects were observed for $\operatorname{NDF}(P \leq 0.022)$ and $\operatorname{ADF}(P=0.009)$, but in practical terms these high-ordered effects were more the result of minor weekly oscillations than overall seasonal patterns. Generally, concentrations of fiber components were greater for OG than for FP, which reflects the more rapid maturation rate noted previously for OG. Considered collectively across all sampling dates, OG exhibited greater concentrations than FP for NDF (60.3 vs. $47.6 \% ; P<0.001), \operatorname{ADF}(33.3$ vs. $25.1 \% ; P$ $<0.001)$, and ADL (2.81 vs. $0.98 \% ; P<0.001)$, and relatively wide differentials were maintained between cultivars across all evaluation dates.

Concentrations of CP decreased in primarily linear $(P<0.001)$ patterns across sampling dates for both oat cultivars (Table 4) from 26.1 to $15.9 \%$ for FP and 21.7 to $13.6 \%$ for OG; generally, CP was greater on all sampling dates for FP than for OG, which further reflects the slower maturation rate for FP. For WSC, sharply contrasting response patterns were observed across sampling dates for oat cultivars. Concentrations of WSC increased throughout the study for FP, reaching a maximum of $17.9 \%$ on November 13 and exhibiting a linear $(P<0.001)$ response coupled with additional quadratic $(P=0.038)$ and cubic $(P=0.011)$ character. For OG, both linear $(P<0.001)$ and quadratic $(P<$ 0.001) effects were observed, in which WSC increased 


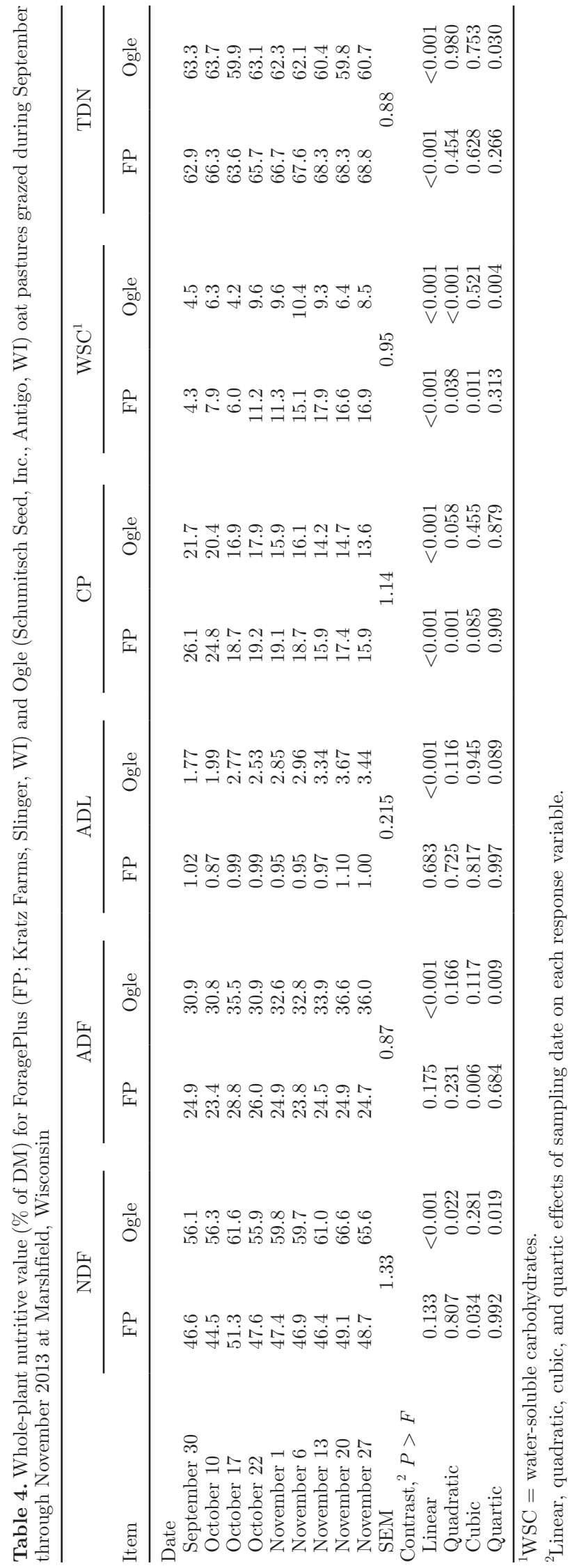

to $10.4 \%$ on November 6 before declining thereafter. Considered across all sampling dates, WSC were greater for FP than for OG (11.9 vs. $7.6 \% ; P<0.001)$, and a differential of at least 1.6 percentage units was maintained on all dates except for September 30. Concentrations of TDN were related closely to WSC; for FP, TDN increased linearly $(P<0.001)$ across sampling dates, without higher-ordered effects $(P \geq 0.266)$, from 62.9 to $68.8 \%$, thereby reflecting the increasing load of WSC present within the forage, particularly throughout November. In contrast, TDN for OG illustrated the normal paradigm for maturing forage plants, declining in a mostly linear $(P<0.001)$ pattern across sampling dates, and reaching a minimum energy density of $59.8 \%$ TDN on November 20.

Forage Nutritive Value 2014. Unlike 2013, interactions of oat cultivar and sampling date were not significant $(P>0.05)$; therefore, only main effect means are presented (Table 5) and discussed. From a practical perspective, concentrations of fiber components (NDF, ADF, and ADL) were very consistent across sampling dates through November 12, before declining slightly over the last week of the study, primarily through dilution by WSC. For each fiber component an effect $(P=0.001)$ of cultivar was observed in which greater fiber concentrations were consistently observed for OG, although these differences between cultivars were minimal in magnitude relative to those observed in 2013. Concentrations of CP declined across sampling dates, exhibiting linear and quadratic $(P<0.001)$ effects; however, oat cultivars only tended $(P=0.063)$ to differ. Both WSC and TDN increased with primarily linear $(P<0.001)$ effects across sampling dates, reaching maxima of 19.5 and $71.9 \%$, respectively, on the final sampling date. No cultivar effects were observed for either WSC or TDN $(P \geq 0.174)$.

\section{Heifer Intakes and Performance}

Intake of Basal Diet 2013. Considered across the entire 67-d period of data collection (Table 6), DMI of the basal diet was greater for $\mathrm{CON}$ than for the grazing heifer groups (645 vs. $428 \mathrm{~kg} ; P<0.001)$ and greater for OG than for FP (464 vs. $392 \mathrm{~kg}$; $P=0.001$ ); however, EG and LG only tended to differ (417 vs. $440 \mathrm{~kg}$; $P=0.071$ ). Similar responses were observed for daily DMI and for daily DMI expressed as a percentage of $\mathrm{BW}$; however, for the latter response variable, LG also was greater than EG (1.24 vs. $1.19 \% \mathrm{BW} ; P=0.033)$. When DMI was expressed as a percentage of CON, OG was greater than FP (71.9 vs. $60.8 \% ; P=0.002)$, thereby suggesting that heifers consumed more oat forage when grazing FP pastures compared with OG. 
Table 5. Whole-plant nutritive value (\% of DM) for ForagePlus (FP; Kratz Farms, Slinger, WI) and Ogle (Schumitsch Seed, Inc., Antigo, WI) oat pastures grazed during September through November 2014 at Marshfield, Wisconsin

\begin{tabular}{|c|c|c|c|c|c|c|}
\hline Treatment & $\mathrm{NDF}$ & $\mathrm{ADF}$ & $\mathrm{ADL}$ & $\mathrm{CP}$ & $\mathrm{WSC}^{1}$ & TDN \\
\hline \multicolumn{7}{|l|}{ Date } \\
\hline September 30 & 47.8 & 25.2 & 0.67 & 22.2 & 7.0 & 65.1 \\
\hline October 6 & 47.3 & 25.0 & 0.79 & 18.9 & 10.4 & 66.1 \\
\hline October 15 & 48.0 & 25.9 & 0.85 & 17.1 & 10.6 & 66.5 \\
\hline October 21 & 47.5 & 25.7 & 0.83 & 15.3 & 13.1 & 67.1 \\
\hline October 27 & 48.0 & 25.6 & 0.91 & 14.1 & 14.3 & 68.1 \\
\hline November 6 & 47.1 & 25.1 & 0.80 & 13.2 & 16.1 & 69.7 \\
\hline November 12 & 47.9 & 26.2 & 0.85 & 14.4 & 13.1 & 68.3 \\
\hline November 17 & 44.4 & 22.5 & 0.47 & 13.5 & 19.5 & 71.9 \\
\hline SEM & 0.65 & 0.42 & 0.087 & 0.56 & 0.79 & 0.52 \\
\hline \multicolumn{7}{|l|}{ Cultivar } \\
\hline ForagePlus & 45.7 & 23.9 & 0.51 & 15.6 & 13.4 & 68.2 \\
\hline Ogle & 48.8 & 26.4 & 1.03 & 16.6 & 12.6 & 67.5 \\
\hline SEM & 0.39 & 0.27 & 0.055 & 0.31 & 0.40 & 0.32 \\
\hline \multicolumn{7}{|l|}{ Contrast, ${ }^{2} P>F$} \\
\hline Linear & 0.008 & 0.004 & 0.249 & $<0.001$ & $<0.001$ & $<0.001$ \\
\hline Quadratic & 0.011 & $<0.001$ & 0.001 & $<0.001$ & 0.451 & 0.180 \\
\hline Cubic & 0.036 & 0.005 & 0.243 & 0.408 & 0.017 & 0.168 \\
\hline Quartic & 0.233 & 0.036 & 0.201 & 0.529 & 0.019 & 0.124 \\
\hline Cultivar & 0.001 & 0.001 & 0.001 & 0.063 & 0.198 & 0.174 \\
\hline
\end{tabular}

${ }^{1} \mathrm{WSC}=$ water-soluble carbohydrates.

${ }^{2}$ Linear, quadratic, cubic, and quartic effects of sampling date on each response variable.

During 2013, weather conditions permitted grazing on $51 \mathrm{~d}$ throughout the fall. When only those days were considered, total DMI was greater for CON than for grazing heifer groups (484 vs. $289 \mathrm{~kg} ; P<0.001$ ), greater for OG than for FP (324 vs. $254 \mathrm{~kg} ; P<0.001$ ), and greater for LG than for EG (301 vs. $277 \mathrm{~kg} ; P$ $=0.022$ ). Similar responses were observed when DMI was expressed on a daily basis, and as a percentage of BW. When DMI was expressed as a percentage of BW, an interaction $(P=0.046)$ of oat cultivar and grazing initiation date was also noted; this was caused by substantially reduced DMI of the basal diet for EG compared and LG for FP pastures, but minimal difference between grazing initiation dates for OG pastures.

Intake of Basal Diet 2014. Logical contrasts for DMI of the basal diet (Table 7) generally identified responses to treatment that were similar to those detected for 2013; however, 2 exceptions were noted. First, grazing heifers consumed substantially less of the basal diet expressed as a percentage of CON during 2014 compared with 2013; this occurred when all days were considered (respective means $=54.2$ and $66.3 \%$ ) or across actual grazing days (respective means $=42.5$ and $58.5 \%$ ), thereby suggesting greater pasture intake during 2014, which is consistent with expectations based on the less mature OG forages throughout October and November of 2014 compared with 2013. Second, when considered across all $57 \mathrm{~d}$ of the trial, reduced total DMI of the basal diet was observed for
EG compared with LG (278 vs. $317 \mathrm{~kg} ; P=0.019)$, and the same response was observed for daily DMI (4.9 vs. $5.6 \mathrm{~kg} / \mathrm{d} ; P=0.019)$.

Heifer Performance 2013. Within grazing treatments, final BCS (Table 6) was greater for EG compared with LG (3.47 vs 3.28; $P=0.012$ ), and the change in BCS during the trial produced a similar effect $(0.54$ vs. $0.22 ; P=0.006)$. Visual evaluation of body condition was corroborated on the basis of total gain, which was also greater for EG compared with LG (54 vs. 29 kg; $P<0.001$ ); in addition, a smaller, but significant, advantage was observed for FP compared with OG (45 vs. $38 \mathrm{~kg} ; P=0.016)$. Similar effects also were observed for ADG, for which EG was greater than LG (0.82 vs. $0.43 \mathrm{~kg} / \mathrm{d} ; P=0.015)$ and $\mathrm{FP}$ was greater than $\mathrm{OG}$ (0.68 vs. $0.57 \mathrm{~kg} / \mathrm{d} ; P=0.015)$. Collectively, ADG for grazing groups did not differ from CON (0.63 vs. 0.64 $\mathrm{kg} / \mathrm{d} ; P=0.619)$. When gain and ADG were calculated from the LG (October 14, 2013) grazing initiation date, grazing groups collectively exhibited greater gain (45 vs. $31 \mathrm{~kg} ; P=0.003)$ and greater ADG (0.86 vs. 0.60 $\mathrm{kg} / \mathrm{d} ; P=0.003)$ than CON.

Heifer Performance 2014. Unlike 2013, no significant contrasts (Table 7) were detected for final BCS (overall mean $=3.29 ; P \geq 0.055$ ), nor were there detectable changes in BCS during the trial (overall mean $=-0.06 ; P=0.325)$. In contrast to 2013 , total gain for $\mathrm{CON}$ was greater than grazing groups (45 vs. 32 $\mathrm{kg} ; P=0.005)$, and total gain from EG was greater 
Table 6. Intakes of basal TMR and growth performance of dairy heifers grazing ForagePlus (Kratz Farms, Slinger, WI) and Ogle (Schumitsch Seed, Inc., Antigo, WI) fall oat for $6 \mathrm{~h}$ daily and supplemented with a blended TMR composed of oatlage and alfalfa haylage during 2013 at Marshfield, Wisconsin; data reflect intakes of forage only

\begin{tabular}{|c|c|c|c|c|c|c|c|}
\hline \multirow[b]{2}{*}{ Item } & \multicolumn{5}{|c|}{ Treatment $^{1}$} & \multirow[b]{2}{*}{ SEM } & \multirow[b]{2}{*}{ Contrast $^{2}$} \\
\hline & Control & Early $^{3}$ & Late $^{4}$ & Early $^{3}$ & Late $^{4}$ & & \\
\hline \multicolumn{8}{|l|}{ Confinement forage intake (all days) ${ }^{5}$} \\
\hline Total, kg/heifer per year & 645 & 376 & 408 & 457 & 471 & 10.0 & I, II \\
\hline Daily intake, $\mathrm{kg} / \mathrm{d}$ & 9.6 & 5.6 & 6.1 & 6.8 & 7.0 & 0.15 & I, II \\
\hline \multicolumn{8}{|c|}{ Confinement forage intake (grazing days only) ${ }^{7}$} \\
\hline Total, $\mathrm{kg} /$ heifer & 484 & 236 & 271 & 318 & 330 & 7.1 & I, II, III \\
\hline Daily intake, kg/d & 9.5 & 4.6 & 5.3 & 6.2 & 6.5 & 0.14 & I, II, III \\
\hline Daily intake, \% BW & 1.78 & 0.88 & 1.01 & 1.18 & 1.21 & 0.017 & I, II, III, IV \\
\hline Percentage of control ${ }^{8}$ & - & 47.8 & 54.9 & 64.4 & 66.8 & 1.49 & II, III \\
\hline \multicolumn{8}{|l|}{ Animal performance } \\
\hline Initial BCS & 3.10 & 2.91 & 3.06 & 2.94 & 3.07 & 0.077 & NS \\
\hline Total gain, $\mathrm{kg}$ & 42 & 58 & 32 & 50 & 25 & 1.9 & II, III \\
\hline Gain from late-start date, $\mathrm{kg}$ & 31 & 59 & 39 & 48 & 34 & 2.2 & I, II, III \\
\hline $\mathrm{ADG}, \mathrm{kg} / \mathrm{d}$ & 0.64 & 0.88 & 0.48 & 0.76 & 0.38 & 0.030 & II, III \\
\hline ADG from late-start date, $\mathrm{kg} / \mathrm{d}$ & 0.60 & 1.13 & 0.75 & 0.92 & 0.65 & 0.042 & I, II, III \\
\hline
\end{tabular}

${ }^{1}$ Treatments consisted of (1) control = heifers maintained in confinement and offered a blended TMR diet (basal diet) composed of oatlage and alfalfa haylage for ad-libitum intake; (2) ForagePlus = heifers allowed to strip-graze ForagePlus fall oat for $6 \mathrm{~h}$ daily (weather permitting) and then supplemented ad libitum with the control diet in the barn; and (3) Ogle = heifers allowed to strip-graze Ogle fall oat for 6 h daily (weather permitting) and then supplemented ad libitum with the control diet in the barn. All heifers, regardless of treatment, received a mean allotment of $0.40 \mathrm{~kg} / \mathrm{d}$ of ground corn during 2013 and 2014; similarly, each heifer received $158 \mathrm{~g}$ of a commercial mineral mix daily during both years of the trial.

${ }^{2}$ Contrasts: (I) control (confined) vs. grazing heifer groups; (II) ForagePlus vs. Ogle grazing heifer groups; (III) early vs. late grazing start dates; and (IV) interaction of II and III. Significance was declared at the $P \leq 0.05$ level of confidence.

${ }^{3}$ Early grazing started on September 30 .

${ }^{4}$ Late grazing started on October 14.

${ }^{5}$ Measurements are based on voluntary intake of the basal diet across all days $(\mathrm{n}=67)$ of the study, including those in which weather did not permit grazing.

${ }^{6}$ Calculated as daily voluntary intake of the basal diet by grazing heifer groups divided by mean voluntary intake of the basal diet by the control (confined) heifer groups $\times 100 \%$. Calculations included all days $(n=67)$, regardless of whether grazing occurred or not.

${ }^{7}$ Measurements are based on voluntary intake of the basal diet only on days $(n=51)$ that weather permitted grazing.

${ }^{8}$ Calculated as daily voluntary intake of the basal diet for grazing heifer groups divided by mean voluntary intake of the basal diet by the control (confined) heifer groups $\times 100 \%$. Calculations included only days that grazing occurred $(\mathrm{n}=51)$.

than LG (39 vs. $24 \mathrm{~kg} ; P=0.002)$. Oat cultivar did not affect $(P=0.185)$ total gain during 2014. Similar responses to treatment were observed for ADG across the 57-d trial; specifically ADG from CON was greater than observed for grazing groups (0.81 vs. $0.57 \mathrm{~kg} / \mathrm{d}$; $P=0.005)$, but this difference was mostly explained by the poor performance of grazing heifers with LG grazing initiation date compared with EG (0.44 vs. 0.70 $\mathrm{kg} / \mathrm{d} ; P=0.002)$. For ADG calculated from the LG grazing initiation date (9 October 2014), no difference between CON and grazing groups (0.72 vs. $0.66 \mathrm{~kg} / \mathrm{d}$; $P=0.427)$ was noted; however, a strong advantage in ADG for EG compared with LG (0.90 vs. $0.42 \mathrm{~kg} / \mathrm{d} ; P$ $=0.001)$ was observed.

\section{DISCUSSION}

\section{Pasture Characteristics}

The interaction of several factors, including cultivar, yearly differences in weather, and planting dates could explain the stark contrasts in growth responses between cultivars observed during 2013 compared with 2014. Forage mass from fall-grown oat can be highly variable from year-to-year, particularly if germination is delayed by insufficient soil moisture; forage mass also can be affected by strong interactions between cultivar and establishment date with late-maturing, forage-type cultivars achieving superior yields with early establish- 
Table 7. Intakes of basal TMR and growth performance of dairy heifers grazing ForagePlus (Kratz Farms, Slinger, WI) and Ogle (Schumitsch Seed, Inc., Antigo, WI) fall oat for $6 \mathrm{~h}$ daily and supplemented with a blended TMR composed of oatlage and alfalfa haylage during 2014 at Marshfield, Wisconsin; data reflect intakes of forage only

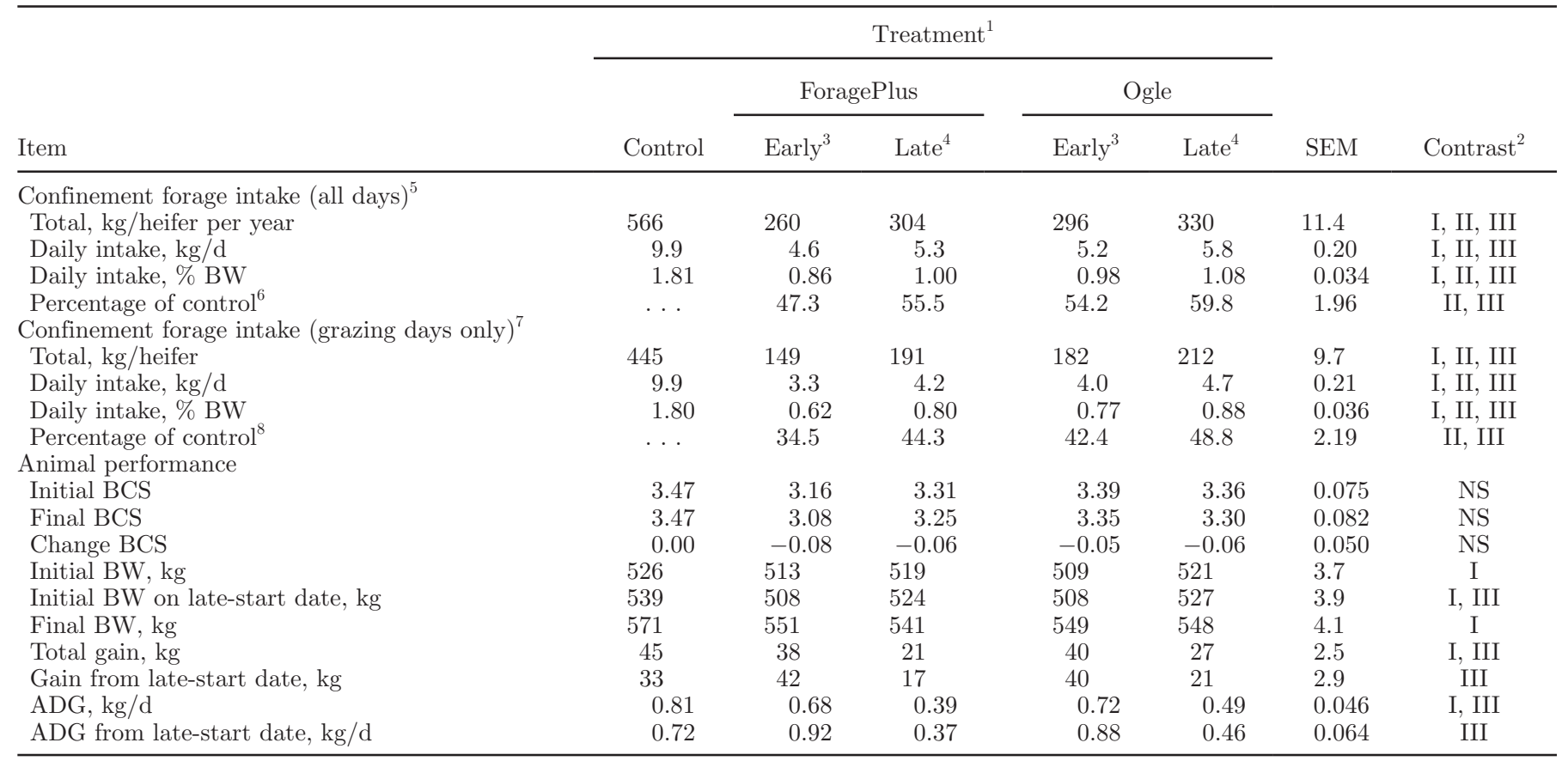

${ }^{1}$ Treatments consisted of (1) control = heifers maintained in confinement and offered a blended TMR diet (basal diet) composed of oatlage and alfalfa haylage for ad-libitum intake; (2) ForagePlus = heifers allowed to strip-graze ForagePlus fall oat for $6 \mathrm{~h}$ daily (weather permitting) and then supplemented ad libitum with the control diet in the barn; and (3) Ogle = heifers allowed to strip-graze Ogle fall oat for 6 h daily (weather permitting) and then supplemented ad libitum with the control diet in the barn. All heifers, regardless of treatment, received a mean allotment of $0.40 \mathrm{~kg} / \mathrm{d}$ of ground corn during 2013 and 2014; similarly, each heifer received $158 \mathrm{~g}$ of a commercial mineral mix daily during both years of the trial.

${ }^{2}$ Contrasts: (I) control (confined) vs. grazing heifer groups; (II) ForagePlus vs. Ogle grazing heifer groups; (III) early vs. late grazing start dates; and (IV) interaction of II and III. Significance was declared at the $P \leq 0.05$ level of confidence.

${ }^{3}$ Early grazing started on September 30 .

${ }^{4}$ Late grazing started on October 9.

${ }^{5}$ Measurements are based on voluntary intake of the basal diet across all days $(\mathrm{n}=57)$ of the study, including those in which weather did not permit grazing.

${ }^{6}$ Calculated as daily voluntary intake of the basal diet by grazing heifer groups divided by mean voluntary intake of the basal diet by the control (confined) heifer groups $\times 100 \%$. Calculations included all days $(\mathrm{n}=57)$, regardless of whether grazing occurred.

${ }^{7}$ Measurements are based on voluntary intake of the basal diet considering only days $(\mathrm{n}=45)$ that weather permitted grazing.

${ }^{8}$ Calculated as daily voluntary intake of the basal diet for grazing heifer groups divided by mean voluntary intake of the basal diet by the control (confined) heifer groups $\times 100 \%$. Calculations included only days that grazing occurred $(\mathrm{n}=45)$.

ment dates (late July to early August; Coblentz et al., 2011), but often this advantage is lost to more rapidly maturing grain-type cultivars when establishment is delayed until mid-August (Coblentz and Walgenbach, 2010a). Establishment dates for our study were somewhat intermediate between these extremes (August 7, 2013, and August 11, 2014). Ignoring interaction with sampling dates, main effect means for forage mass (Table 2) indicated no difference $(P=0.781)$ between cultivars in 2013 despite sharp differences in plant maturity, in which OG reached the early-heading stage of growth (stage $=50$ ) by September 30, but FP never matured beyond the late stages of stem elongation (stage $=37)$. Although these maturity differences had no practical effect on forage mass, they had profound effects on canopy height, leaf percentage, and nutritive value, with OG plants (depending on sampling date) being 9 to $27 \mathrm{~cm}$ taller, containing 22.7 to 30.7 percentage units less leaf tissue, and exhibiting from 2.6 to 8.5 percentage units less TDN than FP on all dates from October 10 or later (Table 4). For FP, little practical change in NDF across all sampling dates was noted; this can be explained in part by dilution of the plant fiber components with WSC, particularly following freezing events occurring during November. Accumulation of WSC during late fall has been observed previously 
(Contreras-Govea and Albrecht, 2006; Coblentz et al., 2012a, 2013b) and has been attributed to the normal winter-hardening process that is common to most winter-annual cereal grains; however, this response also can be affected disproportionately by plant growth stage (Eastin and Sullivan, 1984; Coblentz et al., 2013b). This was corroborated during 2013, when concentrations of WSC within slower-maturing FP oat ranged from 16.6 to $17.9 \%$ across the last 3 sampling dates, whereas the more physiologically advanced OG was far less responsive to cold temperatures (6.4 to 9.3\%).

In contrast to the sharp maturity differences between the 2 oat cultivars observed during 2013, maturity differences between cultivars during 2014 were only modest, but they still differed significantly $(P<0.001$; Table $3)$. Although the physiological growth stage of both oat cultivars generally remained prebooting throughout the fall, OG remained slightly more advanced physiologically, thereby resulting in $\mathrm{OG}$ oat being taller (62 vs. $53 \mathrm{~cm} ; P=0.002)$, producing more forage mass $(4,034$ vs. $3,489 \mathrm{~kg} / \mathrm{ha} ; P=0.035)$, and partitioning less DM into leaf tissue ( 56.6 vs. $66.8 \% ; P<0.001$ ) than FP (Table 3). These overall differences in growth characteristics also were reflected in greater concentrations of NDF (48.8 vs. $45.7 \% ; P=0.001$; Table 5 ), $\mathrm{ADF}$ (26.4 vs. $23.9 \% ; P=0.001$ ), and ADL (1.03 vs. $0.51 \%$; $P=0.001)$, but from a practical perspective, these statistical differences can only be considered minimal in magnitude compared with 2013. The low concentrations of ADL observed for FP during 2013 and for both cultivars during 2014 have been described previously for fall-grown oat (Coblentz and Walgenbach, 2010a; Coblentz et al., 2013b). This likely can be attributed to disruption of the long-day photoperiod requirement for flowering (Dennis, 1984), as well as a much cooler growing environment compared with traditional spring establishment, because lignification is known to be positively associated with temperature for many forage plants (Ford et al., 1979; Van Soest, 1982). Normally, ADL would be expected to comprise approximately $10 \%$ of NDF for headed-oat forages grown under traditional management with a summer harvest (NRC, 2001); however, percentages of ADL within NDF were far less in these studies with the maximum occurring for $\mathrm{OG}$ oat on November 20, 2013 (5.5\%; Table 4), and all sampling dates during 2014 were $<2 \%$ of NDF (Table 5). Limited lignification has been associated with extensive estimates of ruminal NDF digestion by in situ methods (Coblentz and Walgenbach, 2010b), and strong inverse regression relationships between 48-h NDF digestibility and ADL have been reported for fall-oat forages [Y $(\mathrm{g} /$ $\mathrm{kg})=0.064 \mathrm{x}^{2}-11.9 \mathrm{x}+891 ; \mathrm{R}^{2}=0.949 ;$ Coblentz et al., 2012a].

\section{Evaluation of Delayed Grazing Initiation Date}

Potential for Early Weather-Related Grazing Termination. From a management perspective, delaying the initiation of grazing until mid-October offers the potential for better accumulation of forage mass before heifers are allowed access to what are effectively stockpiled oat pastures. One potential problem with this approach was known before the trial was conceived, and relates to the potential for forced early termination of grazing due to accumulated snowfall before all the oat forage can be used by grazing livestock. Based on the results of our study and our previous work (Coblentz et al., 2014), producers in central Wisconsin should assume grazing will be terminated by approximately December 1 each fall, and any forage remaining after that date will likely be wasted. Management options are available to many producers that can limit this risk, such as the potential to alter stocking rates by adding additional heifers or removal of some excess forage as a silage crop about November 1 . An additional aspect of weather-related management is the complexity of moving a lead wire regularly once the ground is frozen solidly; tread-in electrical fencing posts work well for this purpose before the ground freezes, but they don't easily penetrate the soil surface on solidly frozen pastures. One management option is to simply remove the lead wire when the ground freezes solidly, thereby allowing livestock access to all of the remaining forage; this will likely reduce forage utilization and increase waste, but this may be a minor management consideration if termination of grazing is imminent because of impending inclement weather.

Potential for Advanced Maturity for GrainType Cultivars. The potential for year-to-year variability with respect to phenotypic expression was evident for OG. During 2013, OG matured very rapidly, reaching an early-heading stage of growth $($ stage $=50$; Table 2) by September 30. The rapid maturation rate resulted generally in poorer-quality forage with less leaf tissue and reduced energy density compared with FP. The reduced energy density for OG compared with FP can be explained by 2 primary factors. First, OG plants were more physiologically mature and exhibited greater concentrations of fiber components, including ADL; second, the advanced growth stage of OG by November 1 (stage $=54$; Table 2) did not permit an aggressive winter-hardening response with respect to accumulation of WSC. Especially high concentrations of WSC have been observed when freezing events coincide with oat plants at the late stem elongation or boot stages of growth (Coblentz et al., 2013b). Perhaps more importantly, OG was less acceptable to grazing heifers than 
FP during 2013 (Table 6), resulting in greater DMI of the basal diet within the barn across all $(\mathrm{n}=67)$ days (71.9 vs. $60.8 \%$ of $\mathrm{CON} ; P=0.002)$ and on $(\mathrm{n}=51)$ days when weather conditions permitted grazing $(65.6$ vs. $51.4 \%$ of $\mathrm{CON} ; P=0.001)$. Furthermore, ADG for heifers grazing OG were poorer than FP across all $(\mathrm{n}=$ 67 ) days ( 0.57 vs. $0.68 \mathrm{~kg} / \mathrm{d} ; P=0.015)$ and days (n $=$ $53)$ from the LG grazing initiation date (0.79 vs. 0.94 $\mathrm{kg} / \mathrm{ha} ; P=0.013)$. During 2014 , maturation rates were slower for OG, and more similar between oat cultivars. The DMI of the basal diet in the barn for 2014 (Table 7) was generally reduced relative to 2013 , but remained greater for $\mathrm{OG}$ across all $(\mathrm{n}=57)$ days $(57.0$ vs. $51.4 \%$ of $\mathrm{CON} ; P=0.046)$ and days $(\mathrm{n}=45)$ when weather conditions permitted grazing ( 45.6 vs. $39.4 \%$ of CON; $P=0.047)$. Despite these differences, no cultivar effect $(P \geq 0.185)$ was associated with ADG in 2014. On the basis of these data, grain-type oat cultivars are somewhat erratic with respect to maturation rate, and their use should be confined throughout central Wisconsin to management situations where late (mid-August) planting dates are necessary.

Animal Performance. Despite a regimented pretrial training program, heifers that initiated grazing LG exhibited ADG that were roughly one-half of those that initiated grazing EG during both 2013 (0.43 vs. 0.82 $\mathrm{kg} / \mathrm{d} ; P<0.001$; Table 6$)$ and 2014 (0.44 vs. $0.70 \mathrm{~kg} / \mathrm{d}$; $P=0.001$; Table 7). Although not compared statistically, ADG gains for EG exceeded those of $\mathrm{CON}$ in 2013, and were slightly less than CON during 2014. Daily gains for EG were within reasonable proximity to the $0.85-\mathrm{kg} / \mathrm{d}$ target suggested by Hoffman (1997), particularly considering the trial (by necessity) bridged a time period in which heifers began their annual adaptation to subfreezing temperatures (Figure 1). Calculated from the LG grazing initiation date, heifers that initiated grazing LG performed especially poorly compared with EG during 2014 (0.42 vs. $0.90 \mathrm{~kg} / \mathrm{d}$; $P=0.001)$, but also compared with LG in $2013(0.70$ $\mathrm{kg} / \mathrm{d}$ ). This occurred despite better energy density for OG oat forage in 2014, and may have been related to colder temperatures (Figure 1) and extended periods of snow cover in November 2014 that could have disproportionately affected the performance of heifers less adapted to grazing and the associated management routines required to perform the trial.

\section{CONCLUSIONS}

Based on the results of this trial, grazing initiation for fall-grown oat should not be delayed into midOctober to stockpile greater forage mass. Reasons for this recommendation include potential for forced early termination of grazing due to extensive snow cover; sharp year-to-year differences in maturation rate and phenotypic expression exhibited by faster-maturing, grain-type oat cultivars that may make the forage less energy dense and less acceptable to heifers; and potentially inadequate time for heifers to properly adapt to grazing routines, while also adapting to subfreezing temperatures and potentially foraging for snow-covered oat forage. Late-maturing, forage-type oat cultivars, such as the FP evaluated in this trial, are not likely to mature beyond early boot stage by late November, and should be preferred choices for grazing when oat is planted in early August.

\section{REFERENCES}

AOAC. 1990. Official Methods of Analysis. 15th ed. Assoc. Off. Anal. Chem., Arlington, VA.

AOAC International. 1998. Official Methods of Analysis. 16th ed. AOAC International, Arlington, VA.

Coblentz, W. K., M. G. Bertram, and N. P. Martin. 2011. Planting date effects on fall forage production of oat cultivars in Wisconsin. Agron. J. 103:145-155.

Coblentz, W. K., M. G. Bertram, N. P. Martin, and P. Berzaghi. 2012a. Planting date effects on the nutritive value of fall-grown oat cultivars. Agron. J. 104:312-323.

Coblentz, W. K., G. E. Brink, P. C. Hoffman, N. M. Esser, and M. G. Bertram. 2014. Fall-grown oat to extend the fall grazing season for replacement dairy heifers. J. Dairy Sci. 97:1645-1660.

Coblentz, W. K., N. M. Esser, G. E. Brink, P. C. Hoffman, and M. G. Bertram. 2013a. Grazing management for fall-grown oat forages. Focus on Forage. Vol. 15. No. 3. University of Wisconsin Cooperative Extension Service, Madison, WI.

Coblentz, W. K., P. C. Hoffman, N. M. Esser, and M. G. Bertram. 2012b. Using eastern gamagrass to construct diets that limit intake and caloric density for dairy heifers. J. Dairy Sci. 95:6057-6071.

Coblentz, W. K. S. E. Nellis, P. C. Hoffman, M. B. Hall, P. J. Weimer, N. M. Esser, and M. G. Bertram. 2013b. Unique interrelationships between fiber composition, water-soluble carbohydrates, and in vitro gas production for fall-grown oat forages. J. Dairy Sci. 96:7195-7209.

Coblentz, W. K., and R. P. Walgenbach. 2010a. Fall growth, nutritive value, and estimation of total digestible nutrients for cerealgrain forages in the north-central United States. J. Anim. Sci. $88: 383-399$.

Coblentz, W. K., and R. P. Walgenbach. 2010b. In situ disappearance of dry matter and fiber from fall-grown cereal-grain forages from the north-central US. J. Anim. Sci. 88:3992-4005.

Contreras-Govea, F. E., and K. A. Albrecht. 2006. Forage production and nutritive value of oat in autumn and early summer. Crop Sci. 46:2382-2386.

Dennis, F. G., Jr. 1984. Flowering. Pages 237-264 in Physiological Basis of Crop Growth and Development. M.B Tesar, ed. Amer. Soc. Agron., Crop Sci. Soc. Amer., and Soil Sci. Soc. Amer., Madison WI.

Dubois, M., K. A. Gilles, J. K. Hamilton, P. A. Rebers, and F. Smith. 1956. Colorimetric method for determination of sugars and related substances. Anal. Chem. 28:350-356.

Eastin, J. D., and C. Y. Sullivan. 1984. Environmental stress influences on plant persistence, physiology, and production. Pages 201236 in Physiological Basis of Crop Growth and Development. M.B Tesar, ed. Amer. Soc. Agron., Crop Sci. Soc. Amer., and Soil Sci. Soc. Amer., Madison WI.

Ford, C. W., I. M. Morrison, and J. R. Wilson. 1979. Temperature effects on lignin, hemicellulose, and cellulose in tropical and temperate grasses. Aust. J. Agric. Res. 30:621-633.

Goering, H. K., and P. J. Van Soest. 1970. Forage fiber analyses (Apparatus, reagents, procedures, and some applications). Pages 8-11 
in Agric. Handbook No. 379. USDA-Agricultural Research Service, Washington, DC.

Gunsaulis, J. L., W. K. Coblentz, R. K. Ogden, R. K. Bacon, K. P. Coffey, D. S. Hubbell III, J. V. Skinner Jr., M. S. Akins, J. D. Caldwell, K. S. Lusby, and S. A. Gunter. 2008. Fall growth potential of cereal grain forages in northern Arkansas. Agron. J. 100:1112-1123.

Hoffman, P. C. 1997. Optimum body size of Holstein replacement heifers. J. Anim. Sci. 75:836-845.

Hoffman, P. C., K. A. Weigel, and R. M. Wernberg. 2008. Evaluation of equations to predict dry matter intake of dairy heifers. J. Dairy Sci. 91:3699-3709.

Kruse, K. A., D. K. Combs, N. M. Esser, W. K. Coblentz, and P. C. Hoffman. 2010. Evaluation of potential carryover effects associated with limit feeding gravid Holstein heifers. J. Dairy Sci. 93:5374-5384.

Mochon, J., and S. Conley. 2014. 2015 Wisconsin oats and barley performance tests. Publication \#A3874. University of Wisconsin Cooperative Extension Service, Madison, WI

NOAA (National Oceanic and Atmospheric Administration). 2002 Monthly station normals of temperature, precipitation, and heating and cooling degree days 1971-2000. Climatography of the United States No. 81. 47 Wisconsin. National Climatic Data Center, NESDIS, NOAA, Asheville, NC.
NRC. 2001. Nutrient Requirements of Dairy Cattle. 7th rev. ed. Natl. Acad. Press, Washington, DC.

SAS Institute. 2010. Version 9.3. SAS Institute Inc., Cary, NC.

Schulte, E. E., J. B. Peters, and P. R. Hodgson. 1987. Wisconsin procedures for soil testing, plant analysis and feed and forage analysis. Dept. Soil Sci. Bull. No. 6. University of Wisconsin, Madison, WI

Stauss, R. 1994. Compendium of growth stage identification keys for mono- and dicotyledonous plants. Extended BBCH scale. Compiled by Reinhold Stauss. Ciba-Geigy AG, Basel, Switzerland.

Van Soest, P. J. 1982. Nutritional Ecology of the Ruminant. Cornell Univ. Press, Ithaca, NY.

Van Soest, P. J., J. B. Robertson, and B. A. Lewis. 1991. Methods for dietary fiber, neutral detergent fiber, and nonstarch polysaccharides in relation to animal nutrition. J. Dairy Sci. 74:3583-3597.

Weiss, W. P., H. R. Conrad, and N. R. Pierre. 1992. A theoreticallybased model for predicting total digestible nutrient values of forages and concentrates. Anim. Feed Sci. Technol. 39:95-110.

Wildman, E. E., G. M. Jones, P. E. Wagner, R. L. Boman, H. F. Troutt Jr., and T. N. Lesch. 1982. A dairy cow body condition scoring system and its relationship to selected production characteristics. J. Dairy Sci. 65:495-501. 